\title{
Looking on Indigo Flycatcher (Eumyas indigo) Hunting Behaviour: Time, Ecology, and Habitat Preference
}

\author{
Agung Sih Kurnianto ${ }^{1}$, Arief Sugiharto ${ }^{2}$, Nia Kurniawan ${ }^{2 *}$ \\ ${ }^{1}$ Study Program of Agrotechnology, Faculty of Agriculture, Jember University, Jember 68121, Indonesia \\ ${ }^{2}$ Department of Biology, Faculty of Mathematics and Natural Sciences, Brawijaya University, Malang 65145, \\ Indonesia
}

Article history:

Submission April 2019

Revised August 2019

Accepted November 2019

*Corresponding author:

E-mail:

wawan@ub.ac.id

\begin{abstract}
Hunting is the main support of life for the insectivores bird of the world. Through an understanding of Indigo Flycatcher behavior character, we compiled new information for the daily behavior of Indigo Flycatcher and Muscicapidae family in general. The study was conducted at 3 periods to interpret the effect of different seasons conditions: the first period (rainy season, 1 - 30 January), the second period (dry season, 1-30 June), the third period (transition season, 1 - 30 November). The research station covers 3 research points $(A=$ edge of the forest, $b=$ garbage dump, c $=$ dense forest. A canonical correspondence (CCA) was used to understand the significance of the interaction between the abiotic factors and season. Based on the observations, the transition of the season became the most preferred moment for Indigo Flycatcher. Indigo flycatcher hunts in a group, both singular and mixed. Point B is the most common location of Indigo Flycatcher hunting activity.
\end{abstract}

Keywords: Behaviour, Hunting, Indigo Flycatcher, Insectivores, Season

\section{Introduction}

In animal behaviour, hunting is one of the crucial activities that can sustain population sustainability. Variation in bird hunting technique is always related to morphological structure and taxonomy [1]. In some species of flycatcher, hunting hirearki directly affects the distribution of resources, such as food and mate [2]. Hunting is the main support of life for the insectivores bird of the world. Hunting, conducted within a group, is characteristic of the process of getting food [3]. Insectivores have developed various forms of communication and collaboration [4]. Indigo Flycatcher (Eumyas indigo) provides a good example in a study of group collaboration in hunting.

Many species of flycatcher have specified shapes through convergent evolution $[5,6]$. These body shapes make it ideal and effective in groups or individual hunt. In this study, we observed Indigo Flycatcher hunting behavior that occurred in TAHURA R. Soerjo, East Java. This highland area became one of the attractive habitats for Indigo Flycatcher [5]. Observations of hunting behavior will reveal the quality of the environment, population, and taxonomy $[7,8]$. Through an understanding of Indigo Flycatcher behavior character, we compiled new information for the daily behavior of Indigo Flycatcher and Muscicapidae family in general.

\section{Material and Methods Study area}

The research was conducted in the protection area of R. Soerjo Forest Park, located in East Java, Indonesia. The research station covers 3 research points with a radius of 20 meters of the rainforest at an altitude of 1,000 - 1,500 masl (Figure 1). Point $A$ is the edge of the forest, near the parking area. Point B is a garbage dump, which located on the edge of the forest. Point $C$ is part of the forest with a tight Dipterocarpaceae canopy cover. The study was conducted at 3 periods to interpret the 

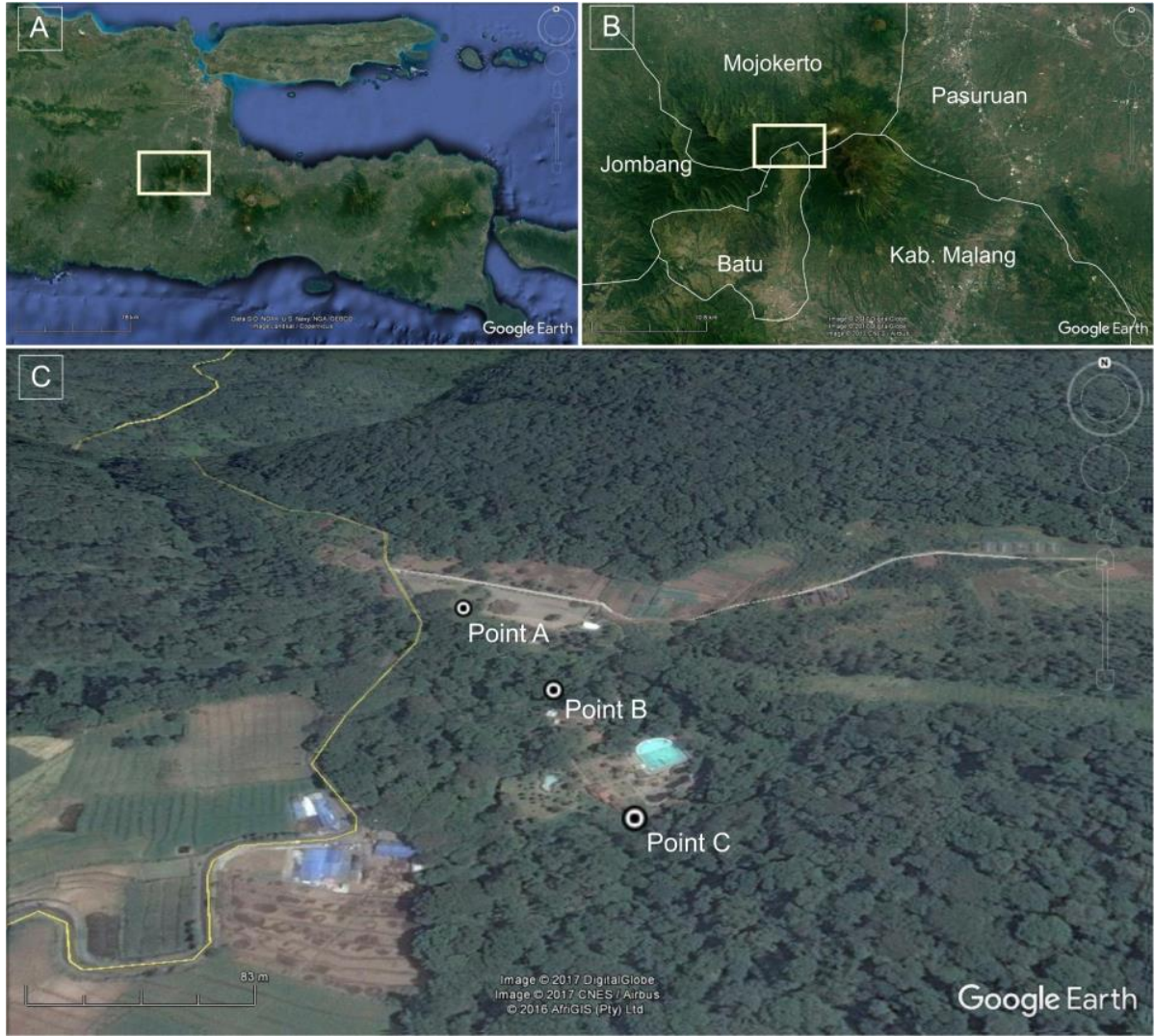

Figure 1. Research location, (a) location on the map of East Java, (b) adjacent location on the Mojokerto-Batu border, (c) distribution of locations into three points: A, B, and C

effect of different seasons conditions: the first period (rainy season, 1 - 30 January), the second period (dry season, 1 - 30 June), the third period (transition season, 1 - 30 November).

\section{Behavioral observations}

The observation was done in three times on every observation day: morning (06.00 - 08.00 $\mathrm{am})$, noon (09.00 - $11.00 \mathrm{am})$ and afternoon $(15.00-16.00 \mathrm{pm})$. Observers take the same point for observation ( $360^{\circ}$-shaped observation). All Indigo Flycatcher hunting activities were observed. Other visible behaviors are also noted. The insectivorous birds present were also observed and recorded in their behavior, especially those with direct links to the Indigo Flycatcher. The observations were performed by NIKON aculon binoculars and canon $1100 \mathrm{D}+75-300 \mathrm{~mm}$ canon lens DSLR camera for documentation.

Observation classification of hunting activities include: 1) Perch activities, covering special activities before or after hunting, 2) Hunting activities (foraging/hunting), including flying style, preycatching style, or other activities observed simul- taneously with this activity, 3) Feeding activities, including the style of eating (direct or chopping), giving it to other birds, or the addition of other unrecorded diets, such as fruit or flowers.

Observation results were included in the table and tabulated. Each classification of observed activity is denoted by a number (each 1) to project a preference form in the chosen habitat then these data were analyzed descriptively.

\section{Statistical analysis}

We used a canonical correspondence (CCA) to understand the significance of the interaction between the abiotic factors and season. It should be noted that although we treat each individual observation as independent data, the birds are not individually marked, so double visits by the same individual can make a slightly erroneous assump tion.

\section{Results and Discussion Visits and behavior}

Based on the observations, the transition of the season became the most preferred moment for 
Indigo Flycatcher (Figure 2). There were 50 main activity, which dominated by hunting, that observed in this season. However, this behavior became less observed during the dry season (43 times). The rainy season is a very unsupportive season, i.e. 36 times observed behavior.

The transitional season is a unique time when many birds begin their 'seen' activities, especially the nurturing of a new generation. Conversely, the rainy season becomes a period when most birds use it by the reproduction process [9]. In addition, the lack of sunlight also reduces the ability of sunbath activity. Birds, however, still require sunlight intake to optimize the body's metabolic system, so this behavior occurs in minimal sun conditions also [10]. Sunbathing has many benefits for birds, such as reducing lice [11], the addition of vitamin D to bone, egg, and feather growth [12] and part of socio-group behaviour [13]. Rainy season and bad weather for days will trigger birds to bask in large amounts when the sun first appeared [14].

The dry season is a time when many birds are observed on the edge of the forest. Some of the water sources in the forest dry out due to minimal rainfall, thus impacting on the availability of feed and feeding areas. However, this is not expected to the significant impact on the behaviour.

The high intensity of hunting in the transitional season is a preparation for the reproduction process that will occur in the following rainy season. An indigo flycatcher is responsible for nurturing chicks for the first 1-2 months. In addition, it takes great energy on the natural processes of mating, such as mating attraction (call or dance) and nesting. Parenting is an inheritance process of hunting tactics from parent to the chicks [15].

\section{Location preference}

Point B is the most common location of Indigo Flycatcher activity, compared to the other two sites (Figure 2). Point $\mathrm{B}$ is a figure of an interesting location for the Indigo Flycatcher to hunt, where the garbage invites many insects. In addition, the vegetation around of garbage dumpster provided perchance for Indigo Flycatcher. Perch is a very important support for insectivore birds to monitor, supervise, improve competitiveness in groups [16], socialize [13], and eat [17].

Activities observed at point $\mathrm{A}$ or $\mathrm{C}$ are quite small. Point A is a form of sharp vegetation gradi-

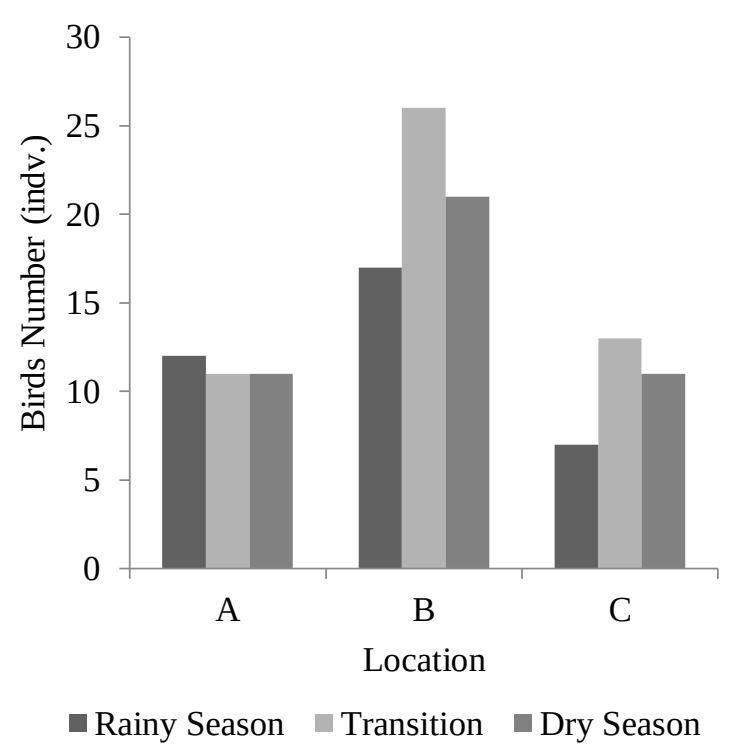

Figure 2. Graph of the relationship between the presence of birds at the study site

ent between tropical forest and a field. This location provides an overview of the hunting habitat that is influenced by intensive human presence. The existence of parking arena, camping ground, and playground allegedly become an influence on animal activities in general. Point $\mathrm{C}$, which is the point of entry of the jungle track, also has quite a lot of disturbance because of its location adjacent to the hot water pool. This location is visited by many people every day.

Human activity and landscape changes have influenced the presence of birds in an area [18]. Noise disturbance as observed at the site may affect egg fecundity and encourage thinning of the shell [19], as well as disrupt bird communications [20]. The rubbish that becomes the location of observation at Point $\mathrm{B}$ is precisely avoided by the public crowd, so birds are more observed. Noise generated by humans greatly disrupts the communication made at the stages of hunting, especially birds that hunt with groups.

\section{Hunting behaviour}

Indigo flycatcher hunts in a group, both singular and mixed. This flycatcher is rarely observed individually in hunting. The Muscicapidae family is known to apply group hunting tactics in their daily activities. This shows the existence of Indigo Flycatcher being part of the success of the insectivore group in make their daily dietary needs. 

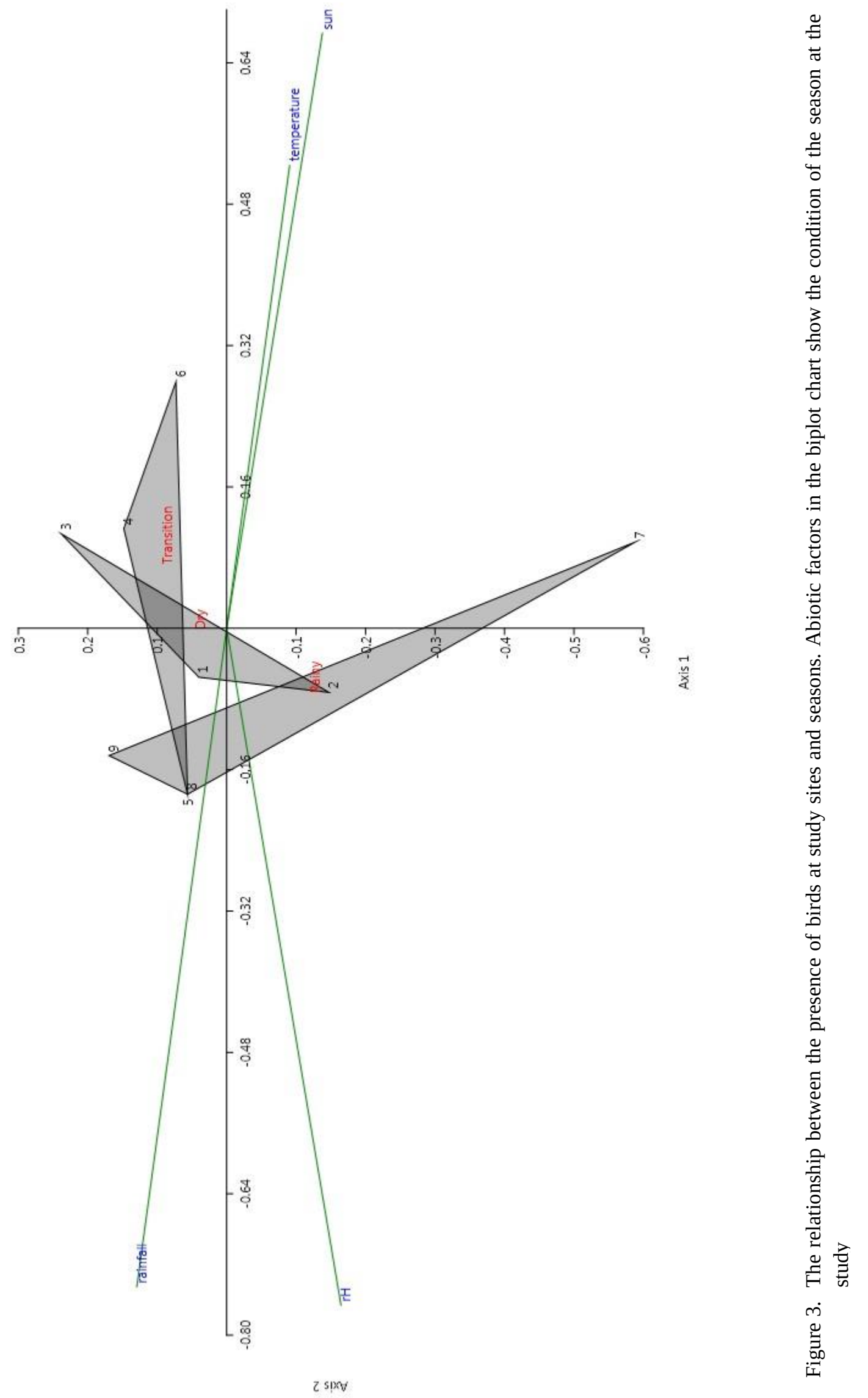
Table 1. Bird species and their role in the study site. We categorize roles based on the majority of observed diets

\begin{tabular}{|c|c|c|c|c|c|c|c|}
\hline \multirow{2}{*}{\multicolumn{2}{|c|}{ Species }} & \multicolumn{3}{|c|}{ Point } & \multicolumn{3}{|c|}{ Role } \\
\hline & & A & B & $\mathrm{C}$ & Insectivore & Frugivore & Nectarivore \\
\hline Leafbird & Chloropsis sp. & - & + & + & $\sqrt{ }$ & $\sqrt{ }$ & $\sqrt{ }$ \\
\hline Sooty-headed Bulbul & Pycnonotus aurigaster & + & + & + & $\sqrt{ }$ & $\sqrt{ }$ & $\sqrt{ }$ \\
\hline Walik Kepala-ungu & Ptilinopus porphyreus & - & + & + & - & $\sqrt{ }$ & - \\
\hline Munguk Loreng & Sitta azurea & - & + & + & $\sqrt{ }$ & - & - \\
\hline Sepah Gunung & Pericrocotus miniatus & + & + & + & $\sqrt{ }$ & - & - \\
\hline Kepudang-sungu Gunung & Coracina larvata & + & + & + & $\sqrt{ }$ & - & - \\
\hline Sikatan Kepala-abu & Culicicapa ceylonensis & - & + & - & $\sqrt{ }$ & - & - \\
\hline Sikatan Belang & Ficedula westermanni & - & + & + & $\sqrt{ }$ & - & - \\
\hline Cingcoang Coklat & Brachypteryx leucophrys & - & + & + & $\sqrt{ }$ & - & - \\
\hline Pelanduk Semak & Malacoccincla sepiaria & - & + & + & $\sqrt{ }$ & - & - \\
\hline Ceret Gunung & Cettia vulcania & - & + & + & - & $\sqrt{ }$ & $\sqrt{ }$ \\
\hline Julang Emas & Rhyticeros undulatus & - & + & - & - & $\sqrt{ }$ & - \\
\hline Anis Sisik & Zoothera dauma & - & + & + & $\sqrt{ }$ & - & - \\
\hline Caladi Ulam & Dendrocopos macei & + & + & + & $\sqrt{ }$ & _- & - \\
\hline
\end{tabular}

A group of Indigo Flycatcher can consist of 2 to 12 individuals. The hunting process begins by a bird (as a pioneer) fly to the observation site. This movement is always accompanied by short whistles, and this bird will soon be followed by other birds. Another group at point $\mathrm{C}$ moves between the high canopy (approximately 15 - 20 meters), while at point $B$ moves from the canopy $(10-15$ meters), toward the perch on the shrubs ( 2 - 3 meters). All group members will perch on twigs, then apply the gleaning or sallying tactic (Figure 3).

Sallying methods are widely applied at points $\mathrm{B}$ and $\mathrm{A}$, where there are open or semi-open areas in front of them. This method is applied by catching insects from perch quickly, then carried with a beak to perch. Hunting results are often directly eaten, but some birds that practice parenting behavior, will feed the insects into their children's mouths.

Sallying method is widely applied by birds family with a type of aerial insect-shaped mouth [21]. Indigo flycatchers have a two-way sallying movement: perch-to-ground or aerial hawk. The perch-to-ground is a direct strike from the perch to the prey, while the aerial hawk is flying vertically before lunging prey. The direction of aerial hawk motion is suspected to be a method of initial observation (skimming) before an ambush. In addi- tion, wing movements in the aerial hawk may disturb the presence of insects in hiding or camouflage [22].

Gleaning method is widely applied at point C, where hunting is more arboreal. Both movements: hovering and direct strike, are applied. Gleaning is widely applied by arboreal birds, such as nuthatch (Sittidae) and woodpeckers (Picidae). Some of these birds have small, pointy beaks to catch without scraping, while the woodpecker has a medium beak to scrape and disassemble the insect's nest [5, 23].

Hunting behavior in mixed groups is often observed at point $\mathrm{C}$, where movement and hunting always occur rapidly and sustainably. The exploration process not only applied on a tree but keep moving to other trees. The mixed groups at points $\mathrm{B}$ and $\mathrm{A}$ have fewer species members and are generally composed only by insectivores and omnivores, such as Little-pied Flycatcher, Grey-headed Flycatcher, and Sooty-headed Bulbul. This evidence made competition exists as an identic ecological role and utilize the same resources.

Based on its ecological role (Table 1), Sootyheaded Bulbul, Javan Cuckooshrike, Grey-headed Flycatcher, Blue Nuthatch, and Fulvous-breasted Woodpecker are potential competitors. The flycatcher groups are more likely to be competitor due to relatively similar roles, hunting tactics, and 
ecological time. Competition is observed at points $\mathrm{B}$ and $\mathrm{C}$, where songs are interrupted or provocative. Sunda Cuckooshrike becomes the main competitor for arboreal hunting, which is seen in Point C. Another arboreal insectivorous, Blue Nuthatch, is rarely seen. This species is a jungle explorer and hunts in a single independent group [5].

The other ecological roles species, Pinkheaded Fruit-dove and Leafbird, do not have a specific relationship to Indigo Flycatcher. The relationship of both is relatively high when forming a mixed group. Fulvous-breasted Woodpecker which is a single insectivore, does not have the potential to be a competitor. The reason is a different tactic.

\section{Conclusion}

The transition is the best time for Indigo Flycatcher to hunt. The garbage dump is the location most visited by the Indigo Flycatcher. Morning becomes the best time for location A, which becomes semi-open area, while afternoon becomes the best activity time for location C. The sallying and gleaning are the most used hunting method by Indigo Flycatcher.

\section{Acknowledgment}

We thank all of Tahura R. Soeryo rangers and local people that help on fieldwork. We thank to staff of Tahura R. Soeryo and all members of Foresters for research permit and advices.

\section{References}

1. Norazlimi NA, Ramli R (2015) The relationships between morphological characteristics and foraging behavior in four selected species of shorebirds and water birds utilizing tropical mudflats. The Scientific World Journal 105296: 1 - 7. doi: 10.1155/2015/105296.

2. Quinn JL, Cresswell W (2004) Predator hunting behaviour and prey vulnerability. Journal of Animal Ecology 73 (1): 143 - 154 doi: 10.1046/j.0021-8790.2004.00787.x.

3. Develey PF, Stouffer PC (2001) Effects of roads on movements by understory birds in mixed-species flocks in Central Amazonian Brazil. Conservation Biology 15 (5): 1416 - 1422.

4. Baker MC (2001) Bird song research: The Past 100 years. Bird Behavior 14 (14): 3 - 50.

5. Mackinnon J, Phillips K, Balen Bv (2000) Burung-burung di Sumatera, Jawa, Bali, dan Kalimantan. Bogor, Puslitbang Biologi - LIPI.
6. Seddon N (2005) Ecological adaptation and species recognition drives vocal evolution in neotropical suboscine birds. Evolution 59 (1): 200 - 215. doi: 10.1554/04-300.

7. Smith JNM, Dawkins R (1971) The hunting behaviour of individual great tits in relation to spatial variations in their food density. Animal Behaviour 19 (4): 695 - 706. doi: 10.1016/s00033472(71)80173-2.

8. Hunter E, Metcalfe JD, Arnold GP, Reynolds JD (2004) Impacts of migratory behaviour on population structure in North Sea Plaice. Journal of Animal Ecology 73 (2): 377 - 385. doi: 10.1111/j.0021-8790.2004.00801.x.

9. Calvacanti LMP, de Paiva LV, Franca LF (2016) Effects of rainfall on bird reproduction in a semi-arid Neotropical region. Zoologia 33 (6): e20160018. doi: 10.1590/s1984-4689zool20160018.

10. Dean WRJ, Barnard P, Anderson MD (2009) When to stay, when to go: Tradeoffs for southern African arid-zone birds in times of drought. South African Journal of Science $105(1-2)$ : 24 - 28. doi: 10.1590/s0038-23532009000100016.

11. Clayton DH, Koop JAH, Harbison CW, Moyer BR, Bush SE (2010) How birds combat ectoparasites. The Open Ornithology Journal 3: 41 - 47. doi: 10.2174/1874453201003010041.

12. Mallet-Rodrigues F (2012) Replacement and growth of primary feathers in captive rock pigeons, Columba livia (Aves: Columbidae). Zoologia 29: 121 - 125. doi: 10.1590/S198446702012000200004.

13. Potter EF (1970) Anting in wild birds, its frequency and probable purpose. The Auk 87 (4): 692 - 713. doi: 10.2307/4083703.

14. Hausser DC (1957) Sun-bathing in Birds. The Wilson Journal of Ornithology 69: 78 - 90 .

15. Moller AP, Javier CJ (2000) The Evolution of paternity and paternal care in birds. Behavioral Ecology 11: 472 - 485.

16. Portugal SJ, Laura S, Graham RM et al. (2017) Perch height predicts dominance rank in birds. Ibis 159 (2): 1 - 7. doi: 10.1111/ibi.12447.

17. Remsen JV, Robinson SK (1990) A classification scheme for foraging behavior of birds in terrestrial habitats. Studies in Avian Biology 13: $144-160$.

18. Kaseloo PA (2005) Synthesis of noise effects on wildlife population: Proceedings of the 2005 International Conference on Ecology and Transportation; North Carolina. Edited by: Irwin CL., Garret P, McDermott KP. 33-35.

19. Burger J (1983) Bird control at airports. Environmental Conservation 10 (2): 115 - 124. doi: 10.1017/S0376892900012200

20. Brumm H, Slabberkoorn H (2005) Acoustic communication in noise. Advances in the Study of Behavior 35:151 - 209. doi: 10.1016/S0065-3454(05)35004-2.

21. Winnasis S (2011) Birds of Baluran National Park. Banyuwangi, Balai Taman Nasional Baluran.

22. Fitzpatrick JW (1980) Foraging behavior of Neotropical Tyrant Flycatchers. The Condor 82 (1): 43 - 57. doi: 10.2307/1366784. 
23. Mayntz M (2017) Bird foraging behaviour: How birds find food. https://www.thespruce.com/bird-foraging-behavior386457. Acessed date: June 3rd, 2017. 
This page is intentionally left blank. 